\title{
Chinese NGOs: Malfunction and Third-party Governance
}

\author{
Huiling Zhang ${ }^{1} \&$ Shoujie Wang ${ }^{2}$ \\ ${ }^{1}$ Social Science Department, Shanghai University of Engineering Science, Shanghai, China \\ ${ }^{2}$ School of Humanity and Law, Shanghai Lixin University of Commerce, Shanghai, China \\ Correspondence: Huiling Zhang, Social Science Department, Shanghai University of Engineering Science, Shanghai \\ 201620, China.
}

Received: November 3, 2015

Accepted: November 18, 2015

Online Published: November 19, 2015

doi:10.5430/ijba.v6n6p66

URL: http://dx.doi.org/10.5430/ijba.v6n6p66

\begin{abstract}
As the speedy development of economy, NGOs in China is also in rapid growth in recent years. The development of Chinese NGOs led to the formation of Chinese-style third-party governance, but the forms in China are different from those in developed countries because such social transformation goals as political democratization, economic marketization and social modernization have not been achieved. The goal of third-party governance in China is to restore the development of NGO's economic, political and social functions, promote benign governance of non-governmental social organizations, government and market, that is, define the respective behavior boundaries of non-governmental social organizations, government and market in order to promote the healthy development of non-governmental organizations in China.
\end{abstract}

Keywords: Chinese NGOs, malfunction, third party governance

\section{Introduction}

In China NGOs generally refer to a variety of social organizations (shehui tuanti), foundations (jijinhui), private non-profit organizations (minban zuzhi or minfei) and grassroots NGOs (caogen zuzhi). Despite the reality that some NGOs do exercise a watchdog function in supervising government policy and action in various fields, it should be noted that the term 'non-governmental' does not necessarily imply that the organization is 'anti-governmental. Chinese NGOs have developed significantly in terms of number, scope, capacity and impact. Yet, most Chinese scholars and NGO practitioners consider the potential of this sector to have largely not been realized, due to severe policy and legislative restrictions. The government has exhibited undeniably contradictory ideas about NGOs. There is some degree of recognition that NGOs provide social services, meanwhile the fear and suspicion that some NGOs may challenge governmental policy and undermine political stability, has resulted in the government strictly controlling the establishment and operation of NGOs. This creates uncertainty, and frequently what the government permits lags behind modern social demands.

In recent years, NGO's malfunction caused the attention of more and more scholars, and professor Lester M. Salomon from John Hopkins Center for Civil Society Studies pointed out the performance of NGO's malfunction: charity inadequate, paternalism, internal governance structure imperfect, amateur approach to professional social problems, only concerned with specific groups but ignored the general population, may be assimilated by environment, bureaucratic tendencies and inevitable tendency for profit. However, Salomon regarded NGO's weaknesses as government's strengths and government's weaknesses just NGOs' strengths. Accordingly, he proposed the theory "partnership of government and NGO," that is, the third-party governance theory. Government will entrust the NGOs to undertake the public services in order to achieve the government's goals, thus the two are interdependent and have respective comparative advantages, the government responsible for financial support while NGO responsible for providing services. (Lester M. Salamon, 2008) Yu Keping, a Chinese scholar, put forward the concept of good governance from the theory, namely, the cooperation of political state and civil society, cooperation of government and non-governmental organizations, cooperation between public agencies and the private sectors, mandatory cooperation and voluntary cooperation.

The background of Salomon's research is based on the US transformation from modernization to modernity, and the significance of its theoretical and practical value to the transition of developing countries needs further study. However, the study of NGO's malfunction and third-party governance has the double meanings in China. Similar to 
developed countries with modernity, NGO promoted the historical change of China's political governance mode from "rule" to "good governance" with its unique organizational characteristics and its mode of action. But it should also be noted that some performance of NGO's malfunction in China also exists, such as patriarchal style, internal governance structure imperfect, administrative trend, the tendency for profit, etc. Thus research on NGO's malfunction and third-party governance has realistic values for China to regulate NGO development and play its service functions in the field of major social welfare and livelihood.

Different from developed countries with modernity, China entered the rapid acceleration period of social transition, coexistence of social optimization and social malady, coexistence of social progress and social costs, coexistence of social harmony and social imbalances, hope and pain accompanied. China has not yet completed the transition task from modernization to modernity. Therefore, research on NGO's malfunction and third-party governance has great theoretical values for promoting the market economy, political democratization and social modernization in China.

\section{Different Forms of Chinese NGOs' Malfunction}

The malfunction of Chinese NGOs' development occurred in social transition process, thus resulting in different forms in China from that in developed countries, for instance, systemic risk, increasing risks of curing classes and organization breakage risks.

\subsection{Institutional Risks in Society}

In contemporary developed countries which have achieved the transition from modernization to modernity, the social organizations are characteristic of autonomy and due to the nongovernmental and nonmarket features of the social organization, they are neither government nor the market appendages. Closely linked to the government and the market on the one hand, but on the other hand, social organizations keep a certain distance with these institutions and don't go with the flow. So to speak, to some extent, the social organizations are the advocates of public rules, also indicators of social trends.

Because of the lack of healthy social organizations, the fault of public rules and awareness are most likely to occur in transformation society. In the analysis of social transition year of the French Revolution, Alexis de Tocqueville, the French historian, sociologist, wrote that people, under the traditional institution but impacted by market economy, do not care about each other and there is special community, simply self-interest, without the participation of social life. (Alexis De Tocqueville, 2012)

For China, now in its social transformation accelerated phase, the subjective and objective conditions of good governance are not mature leading to the emergence of institutional risks. The risks of current Chinese society come from its social structure, for instance, expansion of government authority, improper transformation of government functions, unjust system, lack of system, system failure, and the corruption of power, widening wealth gap, social security lag are its specific appearance.

\subsection{Increased Risks of Curing Classes}

The so-called class curing risks refer to the possibility of unjust hierarchical structure leading to social instability. The functions of NGOs are to regulate the income gap, building a firewall between the disadvantaged and the market, avoid the phenomenon that the rich get richer and the poor get poorer, more importantly, correct market failures, promote mutual mobility between different sectors of society to prevent solidification classes.

Currently the prominent social risks in China are like this: vulnerable major groups, fragile middle class, elite alliances. At present, China has formed an elite and a huge bottom of society, and according to some scholars, the low-income strata accounted for about 80 percent of the total national population. In such social structure, the social capital of elites can exchange, while the lower group is like a mess, and the gap between the rich and the poor widened gradually. Chinese social structure presents 'inverted T-shape', and very fragile social tension.

\subsection{Organization Breakage Risks}

Organizational risks are caused by immature social organization development and ineffective social organization, thus resulting in poor public interest expression channels, and the possibility of social disorder and triggering social conflicts. The functions of NGOs lie in correcting government failure to provide institutional interest expression for members of society, vent their discontent on society timely and appropriately, thus building the social safety valve, the safe, effective, two-way interaction between government and the public to reduce or avoid the outbreak of social conflicts.

However, due to lack of institutionalized interest expression system, the group conflicts in Chinese population expand. According to statistics, the conflicts rose from 8,709 cases in 1993 to 87,000 cases in 2005, and the number 
of mass incidents increased almost one times from 2006 to 2012. (Lu, Xueyi, etc., 2012) China's current organizational risks are mainly manifested in two aspects, social organizations hypoplasia and organizational effectiveness missing. The former reflects the lack of social organizations in China, per capita less, while the latter shows that society organizations play very limited social functions in China and cannot meet the needs of the community.

\section{Social Causes of Chinese NGOs' Malfunction}

Different from developed countries, Chinese NGOs' malfunction mainly lies in incomplete political democratization, market-oriented economy and social modernization required by modernity. Specific performances are as follows:

\subsection{Small Development Space for Chinese NGOs}

Government applies the dual management, but the degree of governance fragmentation is amazing. Different government departments carry out their own management, and management responsibilities are not clear. Thus registration costs and the access threshold are very high, leading a large number of grass-root organizations outside the supervision of government.

Now Chinese government directly manages a large number of social affairs, so function transformation process lags behind the needs of community. And many social organizations are separated from government departments, with the agencies, personnel, facilities mostly from government, and mostly led by leaders of government departments. Chinese NGOs associates closely with government departments, resulting in Chinese NGOs' strong dependence on government, and lower level of autonomy.

Therefore, social organizations lack required rights, resources, space and opportunity necessary for survival and development. More seriously, long-term no separation between government and society will cause more harm to social atmosphere of society, public morality and so on. If the government in a democratic country replaces the community everywhere, then the risks of this country in ethics and knowledge will not be less than the risks in business sector. (Alexis De Tocqueville, 2002)

\subsection{Chinese GOs' Weak Social Influence}

In recent years, China's social organizations developed rapidly, and based on "Development of Civil Affairs Statistical Bulletin", the number of Chinese NGOs increased from 4,446 in 1989 to 431,000 in 2009. The average annual growth rate of 34\% exceeded China's economic growth rate of 9.6\%. (Social Development Research Group of State Council Development Research Center, 2011) Despite the rapid development of NGOs, the influence on society and on policy are far less than some state-owned monopoly enterprises.

Traditionally, people consider that large organizations have more power than small organizations, but Olsen believes that small organizations have more power than large organizations because it is difficult for large organizations to take collective actions and free rider phenomena often exist, while it is easy for small organizations to take collective actions because costs of decision is low. (Mancur Olson, 2004)

Although the number of Chinese state-owned enterprises of monopoly is relatively small, many consumers and stakeholders think large numbers of interest groups are forming in China. They have no efficiency, use public power to plunder, but their annual interests are trillions, leading to the loss of social justice. Especially since the financial crisis, government's intervention in the economy has become the trend, which will bring great dangers to government and society.

Therefore, the formation of large interest groups makes the flow between social classes difficult, increasing the risk of social conflicts.

\subsection{Chinese NGOs' Property Variation}

In recent years, Chinese NGOs also have the tendency of commercialization and profit just like developed countries. To make up for the shortfall in funds, some non-governmental organizations were forced to seek profit, and some learned from the experience of commercial enterprises in order to improve the efficiency. Driven by market profit, it is increasingly more difficult to maintain the traditional sense of independence and public welfare position.

There are still some problems typical in China, for instance, state-owned enterprises undertake social functions, especially some of the large state-owned enterprises bear a heavy burden of society, mainly involved in profit and profit distribution. The boundaries between Chinese enterprise behaviors and social welfare organizations are not clear, resulting from the conflict of each department's rules of law acting on its own. In modern developed countries, the boundaries are very clear, that is, enterprises and non-governmental organizations are both profitable, but their 
differences can be listed------profit dividends can be divided among shareholders, while non-profit organizations can be profitable, but dividends can not be divided by shareholders.

Chinese non-governmental organizations stipulate that profit can not be dividend according to the provisions of private enterprise regulations, but implementation regulations of private education promotion law allow the investors obtain certain proportion of returns from the surplus of the school running according to private schools' articles. Such numerous and conflicting legislation regulations deviate from the public purposes of non governmental organizations, resulting in the commercial tendency of non governmental organizations.

In addition, the development of Chinese NGOs is not mature, the specific performance being the internal system is not standardized, lack of transparent honesty and self-discipline mechanism. 13.7\% have not set up the board of directors, $44.6 \%$ assemble a meeting every six months, and 50\% without information disclosure. (Social Development Research Group of State Council Development Research Center, 2011)

To sum up, the lack of third party governance function of non governmental organizations in China was not caused by weak ability of NGOs, but caused by the lag of government functions transformation, the lag of market transformation process, and the vague boundary of enterprises behaviors and social welfare behaviors.

\section{Methods to Achieve the Third-party Governance}

NGOs' protection of vulnerable groups in society and endorsement of public welfare not only highlight the powerful force, but also build a kind of new mechanism, that is, through the platform of NGOs, introduce the public's participation in administrative decision-making so as to form pluralistic governance model in society. The target of third-party governance in Chinese mainland is to promote good governance of non-governmental social organizations, government and market. The logic thinking of such governance is to define the behavior borders among non-governmental social organizations, government and enterprises, and promote the healthy development of non-governmental organizations.

\subsection{Clarify Boundaries between Government and Corporate Behaviors}

The separation between government and enterprise was put forward at the beginning of the reform, but still did not meet the envisaged objective. The relationship between government and enterprises has actually been in a paradoxical state, on the one hand, for the consideration of state-owned assets' value increasing, government still implemented administrative intervention for different reasons, in various identities (Chief Executives before, representatives of state-owned shares later), which is the widespread phenomenon in China, on the other hand, government, as representatives of state-owned asset ownership, did not fulfill its duties completely because of restricted information, benefits, labor and other factors, thus causing a considerable part of the state-owned assets out of control and a large number of state-owned assets running off, more seriously, crowding out the development space and resources needed by NGOs, aggravating the appearance of different social conflicts and social problems.

\subsection{Perfect Governance Structure within Organizations}

Government, non-governmental organizations and citizens can interact in the tripartite manner. Meanwhile, the separation can be achieved by the following measures: regulate the respective boundaries of NGOs and corporate behaviors, solve such problem as different restrictions to non-governmental organizations, in other words, different regulations in different government departments, improve NGO Council, the Board of Supervisors, strengthen effective management of NGOs' seniors, weaken government's supervision to NGOs' access system, and strengthen government's supervision to NGOs' activities process, and strengthen social supervision, regulate industry supervision, strengthen industry self-discipline, etc. by independent third party regulatory bodies.

\subsection{Clarify Boundaries between Government and NGO Behaviors}

To social organizations, Chinese government has currently taken on the system of dual management, centralized registration, hierarchical management. Although such system played a significant role in promoting the development of social organizations, there still exist conflicting and contradictory regulations and management system. The path to promote the separation of government and society is to solve the problem of overlapping functions of government and NGOs, that is, overlapping functions of government in public services partially stripped to the relevant civil society organizations. In addition, it is necessary to separate government's executive power and grassroots autonomy, solve the institutional problem of government-dominated society.

\section{Conclusion}

At present, Chinese citizens' demand for and the actual supply of public service and public goods are contradictory, leading to the severe challenges for social governance. It can be said that Chinese society is undergoing significant 
changes and transformation, and it is a long way to build third-party management model to improve the level of social governance. As an important element of the third-party governance, Chinese NGOs can not only become the government's help to supplement the public welfare, but also act as the more effective social control intermediary between the state and society, the state and individuals, and play a good cushioning effect in the stability and development of social transformation.

\section{References}

Alexis De Tocqueville. (2002). Democracy in America. Beijing: Commercial Press.

Alexis De Tocqueville. (2012). The Old Regime and the French Revolution. Beijing: Commercial Press.

Lester M. Salamon. (2008). Partners in Public Service. Beijing: Commercial Press.

Lu, Xueyi, etc. (2012). 2013 China Social Situation Analysis and Prediction. Beijing: Social Sciences Academic Press.

Mancur Olson. (2004). Logic of Collective Action. Shanghai: Shanghai People's Publishing House.

Social Development Research Group of State Council Development Research Center. (2011). Society Organizations Construction: Reality, Challenges and Prospects. Beijing: China Development Press. 